Diana Walawender

\title{
Obraz Rumunii we wspomnieniach Kazimiery Illakowiczówny. O tułaczce poetki w latach 1939-1947
}

\author{
... Jestem pewna, ze tysiace wyrzucone z owocnej \\ i potrzebnej pracy czuly, czuja to, co ja czulam: \\ rozpacz i groze, nie - ze co ja teraz poczne? \\ nie-że co ze mna bedzie? (...) Skazanie na bezruch, \\ cierpienie bezwladu, wszyscyśmy przez \\ to przeszli, nawet jeszcze przechodzimy: jakby \\ przestawala krażyć krew, jakby się zapadalo w letarg... ${ }^{1}$
}

\section{„The image of Romania in the memories Kazimiera IHakowiczówna. About the war wandering of poet in the years 1939-1947"}

\begin{abstract}
The article concerns Kazimiera Iłłakowiczówna's war experiences, covers the period from 1939 to 1947, from staff's evacuation of the Ministry of Foreign Affairs to Romania (including the poet) to the moment of passport's receipt, when she could come back to the country. The analysis is based
\end{abstract}

K. Ilłakowiczówna, Niewczesne wynurzenia, Warszawa 1958, s. 48. 
on her sketches, memoirs and literary reportage about Romania. The poet highlighted the beauty of Romanian scenery, praised inhabitants' virtues and showed her feelings in foreign country. Romania played an important role in Iłłakowiczówna's memoirs. On the one hand was this country an important moment in her "wandering through life", which caused sorrow and loneliness, but on the other, Romania was very close to her. Poet recollected the country with luxuriant flora, hospitality of its inhabitants. She gave there lectures on the Marshal Józef Piłsudski, after his death. She left in Romania a part of her own life. Iłłakowiczówna was grateful for opportunity to live there and commune with Romanian culture and language.

Keywords: Illakowiczowna, war, Romania, Pilsudski, interment, poetry.

\title{
„Obraz Rumunii we wspomnieniach Kazimiery Illakowiczówny. O wojennej tulaczce poetki w latach 1939-1947"
}

\begin{abstract}
Abstrakt
Artykuł dotyczy wojennych losów Kazimiery Iłłakowiczówny, obejmuje lata 1939-1947- od ewakuacji pracowników Ministerstwa Spraw Zagranicznych do Rumunii (w tym samej poetki) do momentu otrzymania przez kobietę paszportu pozwalającego na upragniony powrót do kraju. Artykuł powstał na podstawie szkiców, wspomnicń i reportaży Iłłakowiczówny, przybliżających obraz Rumunii. Poetka podkreśla piękno rumuńskiego krajobrazu, wychwala zalety mieszkańców, ukazuje uczucia towarzyszące jej w obcym kraju. Rumunia zajmowala we wspomnieniach Iłłakowiczówny szczególne miejsce. Z jednej strony była kolejnym punktem jej „wędrówki przez życie", tułaczki, która przysparzała jej zmartwień, niepokojów i osamotnienia, $z$ drugiej natomiast strony stała się jej bardzo bliska. $Z$ wielkim zachwytem wspominała kraj charakteryzujący się bujną roślinnością, słynący z gościnności ludzi, gdzie mogła niedługo po śmierci Marszałka Józefa Piłsudskiego mogła wygłaszać odczyty dotyczące jego osoby i gdzie
\end{abstract}


zostawiła cząstkę siebie. Iłłakowiczówna była dozgonnie wdzięczna za możliwość obcowania z rumuńską kulturą, językiem.

Słowa klucze: Iłłakowiczówna, wojna, Rumunia, Piłsudski, internowanie, poezja.

Kazimiera Iłłakowiczówna urodziła się 6 sierpnia 1888 r. w Wilnie (zapis w dokumentach wskazuje na datę 19 sierpnia 1892 r.) jako nieślubna córka Klemensa Zana ${ }^{2}$ i Barbary Iłłakowiczówny (w dokumentach jako rodzice zostali zapisani brat i bratowa matki: Jakub i Eugenia ze Stempkowskich Iłłakowiczowie) $)^{3}$, wnuczka Tomasza Zana, poety. Po śmierci rodziców wychowywała się u krewnych na Witebszczyźnie, później u Zofii Plater-Zyberków Buynowej, w Stanisławowie na Łotwie oraz w Warszawie. Zadebiutowała wierszem Jabłonie wydrukowanym w „Tygodniku Ilustrowanym" w roku 1905. Podróżowała do Szwajcarii, była słuchaczką uniwersytetu w Oxfordzie w Collage Norham Hall dla cudzoziemek. Podjęła studia na Uniwersytecie Jagiellońskim w Krakowie z zakresu filologii polskiej i angielskiej. W latach 1917-1918 była korektorką w drukarni w Petersburgu. W roku 1918 powróciła do kraju i zamieszkała w Warszawie. Pracowała jako urzędniczka w Ministerstwie Spraw Zagranicznych (MSZ), a od maja 1926 do 1935 roku w Ministerstwie Spraw Wojskowych (MSW) na stanowisku osobistego sekretarza Józefa Piłsudskiego. Jednocześnic kontynuowała twórczość literacką, ogłaszając liczne wiersze i przekłady w czasopis-

2 Dopiero po śmierci poetki dzięki Marii Korniłowiczównie (Wnuczka promienistego Tomasza „Odra" 1983, nr 9) wyszły na jaw informacje dotyczące tego, kim był ojciec Ilłakowiczówny. Był nim Klemens Zan- wileński adwokat, syn Tomasza Zana, przyjaciela Adama Mickiewicza, poety i jednego z zalożycieli Towarzystwa Filomatów. Zan mial już rodzinę, ale gdy poznał chórzystkę, nauczycielkę języków Barbarę Itłakowiczównę wdał się w romans, który zaowocował dwiema córkami, a jedną z nich była Kazimiera Iłłakowiczówna.

3 Według B. Zan-Czerwijowskiej, Kazimiera Illakowiczówna. Lata dzieciństwa i mlodości (1) „W Drodze" $1991 \mathrm{nr} 2$.

4 Powrót do kraju w roku 1918 stanowil istotny przełom w życiu poetki. Została przyjęta do Ministerstwa Spraw Zagranicznych jako młodszy referent, a później, po przewrocie majowym objęla stanowisko sekretarza ministra. Ową ,pozycję" Iłłakowiczówna z pewnością zawdzięczała nie tylko doskonałej znajomości języków obcych, czy jednoznacznych deklaracjach ideowych dla Marszałka, ale także powiązaniom litewskim i koneksjom rodzinnym. Traktowała swoją pracę w ministerstwie jako pewien rodzaj twórczości. Postawa stawiająca znak równości między działalnością artystyczną a „,zziałalnością zza urzędniczego biurka" była czymś nowym. 
mach: „Bluszcz”, „Kurier Polski”, „Skamander”, „Słowo”, „Wiadomości Literackie”, „Polska Zbrojna”, „Kurier Poranny”. Laureatka wielu nagród: Nagrody Literackiej Miasta Wilna za twórczość poetycką (1930), Państwowej Nagrody Literackiej i Złotego Wawrzynu PAL (1935), I nagrody w zorganizowanym przez Komisję Kulturalno-Oświatową przy Komitecie Obywatelskim dla Spraw Opieki nad Uchodźcami Polskimi na Wegrzech konkursie na utwory literackie napisane na uchodźstwie. Odznaczona została Krzyżem Oficerskim Orderu Odrodzenia Polski, Krzyżem Komandorskim (1974), Krzyżem Komandorskim z Gwiazdą (1981), Komandorią Korony Rumuńskiej, francuskim Krzyżem Legii Honorowej, Złotym Orderem Pracy Węgierskiej Republiki Ludowej (1978). Była członkiem Polskiego PEN Clubu. Po wybuchu II wojny światowej została ewakuowana wraz z innymi pracownikami MSZ do Rumunii, przebywała w Klużu w Siedmiogrodzie. W roku 1947 powróciła do kraju i na stałe zamieszkała w Poznaniu, gdzie zajmowała się twórczością literacką i udzielaniem lekcji z języków obcych. W 1956 roku otrzymała Nagrodę Miasta Poznania za całokształt twórczości poetyckiej, nagrodę Fundacji A. Jurzykowskiego w Nowym Jorku (1966), nagrodę Ministra Kultury i Sztuki I stopnia (1967), nagrodę paryskiej „Kultury” za całokształt twórczości (1971) oraz wiele innych nagród. W 1981 roku przyznano poetce doktorant honoris causa Uniwersytetu im. Adama Mickiewicza w Poznaniu. Przed wojną Kazimiera Iłłakowiczówna wydała m.in. następujące tomiki poetyckie: Kolędy polskiej biedy (1917), Trzy struny (1917), Śmierć Feniksa (1922), Obrazy imion wróżebne (1926), Zwierciadlo nocy (1928), Ballady bohaterskie (1934), Slownik litewski (1936), a po wojnie: Poezje 1940-1954 (1954), Lekkomyślne serce (1959), Szeptem (1956). Ogłosiła tom prozy poetyckiej Z rozbitego fotoplastykonu (1959), szkice Niewczesne wynurzenia (1958), Trazymeński zajac (1968), tom utworów dramatycznych: Rzeczy sceniczne (1969). Zmarła w roku 1983, a pochowana została na Cmentarzu Powązkowskim w Warszawic ${ }^{5}$.

Kazimiera Iłłakowiczówna należy do uznanych poetek, a świadczy o tym szereg publikacji, które wydano na jej temat ${ }^{6}$.

5a podstawie: Itlakowiczówna Kazimiera 1888-1983 [w:] Wspótcześni polscy pisarze i hadacze literatury. Slownik biobibliograficzny, pod red. J. Czachowskiej, A. Szalagan, t: 3, G-J, Warszawa 1994, s. 294-299.

6 Cenne spostrzeżenia dotyczące sylwetki i twórczości Kazimiery Iłłakowiczówny można znaleźć m.in. w: 
Rok 1939 wyznacza ważną datę w życiu Kazimiery Iłłakowiczównyniemal od pierwszych dni wojny rozpoczęła tułaczkę. Nie mogła się ona równać z żadnym $z$ wyjazdów m.in. do Oxfordu, czy wyjazdami dyplomatycznymi w okresie pracy w Ministerstwie Spraw Zagranicznych. Poetka nie była już studentką, ani tym bardziej dostojnikiem państwowym, który wygłaszał prelekcje o Polsce w różnych zakątkach Europy, lecz stała się zwykłą uciekinierką pozbawioną domu. Lata 1939 -1947 będą więc stanowiły okres, w którym przebywała ona za granicą, a dokładniej w Rumunii. Ogromnym rozczarowaniem był dla niej fakt, że, mimo iż była silna i pełna energii znalazła się nikomu niepotrzebna w Siedmiogrodzie. Nie mogła wrócić do kraju, a przy tym nie była przygotowana na cios, gdy okazało się, że rząd emigracyjny nie zamierza skorzystać z jej usług i doświadczenia?:

Dopiero utknięcie u obcych po klęsce Polski, utknięcie z paszportem dyplomatycznym wśród narodu, który powinien był ten paszport uszanować, sprawiło, że zaczęłam się mocno poczuwać do jakiejś godności ogólniejszej i pilnować troskliwie, aby się tej godności, którą nazywałam w sobie narodową, nie działa ujma (...) Paszport dyplomatyczny, przedmiot mojej nieustającej dumy od tylu lat niepodległej Polski, nagle stał się czymś, czego lepiej było nie pokazywać, raczej zaopatrzyć się w inny8.

Wstyd zrodził się z poczucia klęski, a ponieważ Iłłakowiczówna reprezentowała „władze państwowe”, poniekąd czuła się odpowiedzialna za taki

\footnotetext{
A. Brzozowska, Pliszka w jaskini lwa, czyli pierwsza dama urzędów Drugiej Rzeczypospolitej, „Kobieta i życie” 1989, nr.43, Ł. Danielewska, Kazimiery Illakowiczówny droga do Polski, „Poezja” 1978, nr 11/12, K. Dybciak, Proza o najdalszych Kresach, „Kresy” 1993, nr 15, T. Fiałkowski, Przypomnienie Illakowiczówny, „Tygodnik Powszechny” 1994, nr 28 , M. Korniłowiczówna, Wnuczka Promienistego Tomasza, „Odra” 1983, nr 9, P. Kuncewicz, Kazimiera Illakowiczówna, „Tygodnik kulturalny” 1963, nr 28, J. Kwiatkowski, Lew i straszydlaki [w:] tegoż, Notatki o poezji i krytyce, Kraków 1975, M. Lalak, Arcystuch Itlakowiczówny, „Nowe Książki” 1997, nr 2, S. Lichański, Liryka Illakowiczówny [w:] tegoż, Literatura i krytyka, Warszawa 1956, T. Lawecki, Poznańska suita Iły [w:] Szlakami stawnych Polaków. Różnorodne oblicza wielkości, b.w., J. Lukasiewicz, Z Illakowiczówna po latach, „Więź” 1998, nr 9, S I. Maciejewska, Utożsamiona ze światem. Kazimiera Itlakowiczówna [w:] Poeci dwudziestolecia międzywojennego, t: 1, Warszawa 1982, B. Mamoń, O wierszach Kazimiery Illakowiczówny, „Tygodnik powszechny” 1955, nr 15, S. Podhorska-Okołów, Księga tęsknoty, „Twórczość” 1959, nr 1 [Niewczesne wynurzenia rec.], J. Ratajczak, Illa proza, „Nowe Książki” 1997, nr 10, J. Siedlecka, Panna Kazimiera [w:] Wypominków ciąg dalszy, Warszawa 1999, P. Szewc, Trzy wybory, „Nowe Książki”1996, nr. 4, L. Żuliński, Godziny z Illa, ,Literatura” 1988, nr 4.

7 J. Ratajczak, Lekcje u Itlakowiczówny (szkice, wspomnienia, listy i wiersze), Poznań 1986, s. 23.

8 K. Iłakowiczówna, $d z$. cyt., s. 61.
} 
stan rzeczy. Cierpliwie znosiła kąśliwe uwagi pod swoim adresem. Tłumaczyła innym, że ludzi, którzy zostali dotknięci katastrofą wojenną należy zostawić w spokoju i nie wolno ich sądzić. Tymi argumentami starała się przekonać samą siebie. Gdy inne kraje doznały klęski, poczucie hańby i wstydu zostało zmazane. Tym samym chciała udowodnić, że wszystko to co przynosiło wstyd i poniżało mogło sprawić, że człowiek był w stanie podjąć największe trudy. Należało jednak przełamać bezruch, samotność, które hamowały wszelkie działania. Tylko tak można było z czystym sumieniem pogodzić się z losem, zapomnieć o tym, co się utraciło, o zaszczytach, pozycji, a przede wszystkim przestać wysuwać pretensje do innych. Jeszcze niedawno przecież jej stanowisku w MSZ towarzyszyła ważna pozycja w literaturze polskiej, a teraz wszystko, co do tej pory osiągnęła zostało przekreślone. Straciła dom, zaszczyt pracy w MSZ, pożegnała się z Warszawą, a przede wszystkim ze środowiskiem, w które wrosła. Co ciekawe, jej życie znowu zatoczyło krąg, ponownie była zmuszona żyć wśród obcych, utrzymywała się z pieniędzy zarobionych na przygodnych zajęciach i w końcu udzielała nauki języków obcych w tym języka rumuńskiego i węgierskiego:

... A ułożyć sobie takie modus vivendi było konieczne, o ile się pragnęło nie sterczeć w żywym otoczeniu jak obce ciało. Mówiłam tylko co o motorze nastawionym na najwyższą skalę pracy. Nie było z nim rady. Motor ruszył. Chciał pracować w jakichkolwiek warunkach i dla kogokolwiek. Szed19.

Droga na kilkuletnie wygnanie rozpoczęla się dla poetki przez Lwów i Zaleszczyki, Dubno, Kuty, Czerniowiec, gdzie jak przyznała:

Byłam jak śrubka, która wypadła z maszynerii: jeszcze mi nie bylo przyszło do głowy pomagać przy paszportach, nie miałam ani grosza rumuńskich pieniędzy, ani dachu nad glową. Jedno tylko wiedziałam na pewno: to, że nie chcę iść do żadnego obozu, nawet gdyby tam było jak najlepsze utrzymanie od rządu rumuńskiego ${ }^{10}$.

Na szczęście u progu konsulatu Iłłakowiczówna trafiła na kolegę Rogera Raczyńskiego ${ }^{11}$, którego poprosiła o parę lei na telefon, a otrzymała od nie-

Tamże, s. 54.

10 Tamże, s. 97-98.

11 Roger Adam Raczyński (ur. 8 grudnia 1889 w Warszawie, zm. 10 listopada 1945 w Atenach), wojewoda poznański i polski dyplomata. Wybuch I wojny światowej zastał go w Rosji. Tam też związał się z Komitetem Narodowym Polskim, w którego pracach brał czynny udział. Po 
go tysiąc. Telefony, które wykonała do znajomych z czasów, gdy wygłaszała w Rumunii pogadanki zorganizowane przez Związki Kobiece wystarczyły by znalazła schronienie. Zatrzymała się u przewodniczącej Związku Kobiet Prawosławnych, Vetturii Gramatoviczi, która wraz z rodziną udostępniła jej pokój swojej córki, ochroniła przed żandarmerią zaganiającą Polaków do obozów, karmiła. Stamtąd Kazimiera Iłłakowiczówna zadepeszowała do kilku rumuńskich miast, prosząc o pracę. Wciąż miała nadzieję, że zostanie wezwana do „wyższych zadań” i będzie pracowała dla „swoich”:

Kto jest sam i nie obaczony rodziną, niech się nie ciśnie do swoich. Próbowałam perswadować, że nie chodzi o rangi i zaszczyty ani o stanowisko równorzędne z uprzednio zajmowanym, że każde wezmę, byle dla swoich pracować. Po cóż znałam te wszystkie języki, którymi władam zarówno w mowie, jak i w piśmie, po co objeżdżałam tyle krajów jednając nam w nich przyjaciól, jeśli w takich czasach mam z tym wszystkim, z tego wszystkiego, żyć tylko dla siebie? ${ }^{12}$.

Pracę otrzymała niedługo potem. Stała siç nauczyciclką języków obcych, w zamian za jedzenie i kąt do spania. Znalazła się w środkowej Rumunii, w dolinie siedmiogrodzkiej, w ogromnym domu gubernatora w Kluż $(\text { Cluj })^{13}$ :

W ogromnym domu, w którym znalazłam się prawie zaraz po przejściu granicy, (bo już 25 września byłam ulokowana u swoich pracodawców), musiałam moją rozpędzoną do olbrzymiej pracy maszynę stonować do najcichszego pianissimo biegu. Wyniszczając życie swoje jak najbardziej z pierwiastków osobistych, usiłowałam przeżywać w sobie

odzyskaniu przez Polskę niepodległości powrócił do kraju i w latach 1918-1921 pracował w MSZ jako uczestnik prac konferencji wersalskiej, I sekretarz poselstwa polskiego w Rzymie, kierownik referatu mniejszości narodowych w MSZ, a następnie delegat MSZ w Komisji Likwidacyjnej w Poznaniu. W 1927 roku byl jednym z reprezentantów wielkopolskiego ziemiaństwa na zjeździe polskich konserwatystów w Dzikowie. Poparł tam wspólpracę z władzami sanacyjnymi. Chcąc pozyskać wrogą pilsudczykom Wielkopolskę organizowal w Poznaniu Unię Katolicką Ziem Zachodnich. Gdy jego próby zawiodly związal się z rządem wstępując do BBWRu, będąc jego wiceprezesem, a następnie prezesem w Poznańskiem. Pomiędzy 4 października 1929 a 1 sierpnia 1934 był wojewodą poznańskim i pomimo związku z sanacją cieszył się poparciem mieszkańców. Od 1934 do 1936 był wiceministrem rolnictwa, a w 1938 powrócił do służby dyplomatycznej jako poseł RP w Bukareszcie. Zastał go tam wybuch II wojny światowej. Jako poseł w Rumunii odegral we wrześniu 1939 r. ważną rolę w powstaniu rządu premiera Władyslawa Sikorskiego w Paryżu na podstawie: Raczyński Roger [w:] Wielka Ilustrowana Encyklopedia Powszechna, tom XIV, Kraków 1998, s. 235.

12 Tamże, s. 49.

13 Tamże, s. 32. 
zbiorowość, na to po prostu, by móc być jak najlepszym urzędnikiem i aby w pisarstwie swoim odzwierciedlić jak najlepiej życie tej zbiorowości ${ }^{14}$.

Iłłakowiczówna sama wspominała w Niewczesnych wynurzeniach, że nie da się opisać samotności, która jej doskwierała w Klużu. By zagospodarować czas i oswoić się ze swoim położeniem wychodziła z domu i wędrowała niczym człowick błądzący na oślep. Nienawidziła pięknego domu i widoku, jaki rozciągał się z jego okien. Pogardzała zbytkiem, luksusem, a ten wewnętrzny bunt spowodował głęboką awersję do języka rumuńskiego. Nie starała się ani go zrozumieć, ani nauczyć. Przełomem, który zmienił jej dotychczasowe nastawienie stało się jak przekonuje poetka - przypadkowe przypomnienie ,proroctwa” zasłyszanego od młodej dziewczyny w Klużu, która mówiła, że Polska będzie po stronic zwycięzców. W jednej chwili kobieta dostrzegła wokół siebie żyzny, gościnny kraj, miejsce, gdzie nie znalazła się przez przypadek, ale przez zrządzenie losu, zgodnie z tradycją urzędu, w którym pracowała, poczuła się ,akredytowana przy królewskim gubernatorze w Klużu"'s:

Kluż jest caly przepleciony wsią: nie tylko rynek czy cygańska tyfusowa dzielnica, gdzie ja mieszkam, ale i plac główny, i wszystkie promenady, miejskie obchody i pochody. Skazana na pobyt w tak malowniczym kraju, jakim jest Rumunia, w jednym tylko mieście, tak sobie wbijam w pamięć wszystkie jego dziwactwa i szczególiki, jak chory, który widzi krajobraz z jednego tylko okna. Kiedy stąd wyjadę, będę w snach błądziła po Klużu; stanę przed kolegium Batorego, zapatrzę się w kamieniczkę, w której nocował Petöfi i - pomodlę się przed domem, gdzie mieszkal Bem ${ }^{16}$.

Wtedy też postanowiła, że musi zacząć uczyć się języka rumuńskiego. Mimo „osobistego dramatu” nie poddała się, podjęła pracę i zrozumiała, że tylko dzięki „rajskiemu chaosowi” udało jej się tak długo utrzymać tam, gdzie była. Pracując u gubernatora jednocześnie narzekała na swoją pozycję w domu. Salon był dla „Państwa”, a sama Iłłakowiczówna jak sama przyznała znała tylko poglądy kuchni na politykę. Tym słowom towarzyszyły rozważania dotyczące zachowania własnej godności i dumy:

\footnotetext{
14 Tamże, s. 40-50.

K. Illakowiczówna, dz. cyt., s. 100.

Tamże, s. 113-114.
} 
To nie przynosi ani mnie, ani memu narodowi żadnej ujmy, przeciwnie- od tych garnków wieść może najprostsza droga do najwyższych jakiś wyróżnieńn ${ }^{17}$.

Obraz Rumunii przywoływała Iłłakowiczówna wiclokrotnic, choć najwięcej miejsca poświęca wspomnieniom z Klużu. Jej zainteresowanie przykuwa każdy, nawet najmniejszy szczegół budujący obraz miejsca, w którym przyszło jej żyć, stąd wiele akapitów Niewczesnych wynurzeń zawiera w sobie opisy np. kwiatów:

Takie same jak u nas przylaszczki i pierwiosnki, to znów niewidziane u nas żółte anemony, tak żólte, tak słoneczne, tak trwałe, że gdybym ich nabrała w chustkę (...), mocne i świeże, aż do Warszawy dowiozła. Liście mają wąziutkie jak koperek, same strzępeczki. A później znów, jak nie zakwitną jakieś nieznane, drobniutkie białe kwiatuszki, ale tak pachnące miodem i jeszcze jakąś domieszką! ${ }^{18}$.

O samym Klużu poetka pisze w następujący sposób:

Piękne to małe miasto, przewiane pamięcią Batorego i Bema, nic nie przypomina. Jest zupełnie swoiste. Klimat ma niezmiernie ostry, ale sądzi o sobie, że jest miastem południowym, toteż domy jego są poprzeszywane galeriami, ludność zaś prowadzi życie agrarne, zdaje mi się przynajmniej, że się to tak nazywa, kiedy wszyscy dzień cały szwendają się po ulicy. A pali się w owych piecach, które nie grzeją, dębem, bukiem, topolą, w najgorszym czasie jodłą. Był czas, że paliłam nawet orzechem włoskim i jabłonią ${ }^{19}$.

Ale i czas chwilowego spokoju zostaje przerwany. 30 sierpnia 1940 roku na skutek arbitrażu wiedeńskiego północno- zachodnia część Siedmiogrodu wraz z Klużem została przekazana pod naciskiem hitlerowskich Niemiec Węgrom. Rumuński Kluż przeobraża się w węgierski Kolozsvar, a Iłłakowiczówna jak najszybciej musiała opuścić willę gubernatora. Jednak, gdy rumuński gubernator opuścił już Kluż, zostawiając na miejscu swoją rodzinę poetka odpłaciła za dobroć, którą otrzymała. Nie odjechała z polskim konsulem, przeciwnie została przy dzieciach i żonie gubernatora, broniąc cudzy dom przed odwetem ${ }^{20}$.

\footnotetext{
17 J. Ratajczak. $d z . c y t$, s. 36.

8 K. Ilłakowiczówna, $d z$. cyt., s. 122.

19 Tamże, s. 127

20 Tamże, s. 37.
} 
Przeobrażenie się Klużu w Kolozsvar rozwinęło prowęgierskie sympatie, których Iłlakowiczówna nie ukrywała już za czasów rumuńskich. Utrzymywała poprawne kontakty z Węgrami, mimo że nie podobało się to rodzinie gubernatora. Nic więc dziwnego, że po roku 1940 rozpoczął się w życiu kobiety czas bardzo owocny, kiedy to nauczyła się języka węgierskiego. $\mathrm{Na}$ prośbę ojca Piotra Wilka-Witosławskiego ${ }^{21}$, który odszukał ją w Kolozsvarze, udała się z odczytem do Budapesztu i za namową „Biblioteki Polskiej" zaczyna tłumaczyć na język polski wiersze Ady' go $^{22}$, ucząc się na nich języka węgierskiego. Owocem przypływu twórczych sił były wiersze, które ukazały się w Budapeszcie: Wiersze bezlistne (1941) czy przekłady z Ady'go (1942).

Problemy, które dotychczas przeszkadzały poetce zeszły teraz na dalszy plan, a dominującym elementem stała się kwestia powrotu do kraju. Już w lipcu 1945 roku Iłłakowiczówna wysłała przez ludzi wracających do Polski podanie do Ministerstwa Spraw Zagranicznych, o możliwość powrotu do pracy. Jednocześnie zebrała na terenie Siedmiogrodu ludzi, którzy chcieli powrócić do Polski. I tak w październiku 1946 roku na liście osób, które wyraziły chęć wyjazdu do kraju znalazły się dwadzieścia

21 Piotr Feliks Wilk-Witosławski urodził się 13 kwietnia 1902 r. w Siedliskach koło Rzeszowa, a zmarł 4 marca 1960 r. w USA w miejscowości Pulaski. Zakonnik, franciszkanin. Do Zakonu wstapił w 1918 r. Studia filozoficzno-teologiczne odbył na Wydziale Teologicznym Uniwersytetu Jana Kazimierza we Lwowie, gdzie też uzyskał stopień magistra teologii. Wyświęcony na kapłana w 1926 r., pracowal w duszpasterstwie i dał się poznać jako dobry misjonarz ludowy i rekolekcjonista. Do wybuchu II Wojny Światowej byl, między innymi, przełożonym w kilku klasztorach. Po wrześniu 1939 r. przedostal się na Węgry i tam pracował do 1944 r., jako kapelan polskich obozów wojskowych i duszpasterz uchodźców. Aresztowany w 1944 r. przez Gestapo i osadzony w obozie koncentracyjnym w Mathausen, a wkrótce potem w Dachau. Odzyskał wolność w 1945 r. i przez Austrię i Wlochy udał się do Stanów Zjednoczonych, gdzie do końca życia pracował, jako duszpasterz środowisk polonijnych na podstawie: http:// www.literatura.gildia.pl/tworcy/piotr feliks wilk witoslawski (odczyt 04.04. 2014 r.)

22 Endre Ady de Diósad (ur. 22 listopada 1877 w Érmindszent, zm. 27 stycznia 1919 w Budapeszcie) - węgierski poeta, Ady pochodził z dobrej, siedmiogrodzkiej rodziny i był starszym $z$ dwojga rodzeństwa. Po ukończeniu ewangelickiego gimnazjum w Zilah, kontynuował edukację na uniwersytecie w Debreczynie. Po powrocie na Węgry Ady rozpocząl pracę dla czasopisma Budapesti Napló, w którym opublikowal ponad 500 artykułów i wierszy. W tym okresie rozpocząl również swą działalność polityczną wstępując do radykalnej grupy o nazwie Huszadik Század (Dwudziesty Wiek). Literacko zaś, będąc ciągle jeszcze pod wrażeniem literatury paryskiej, stworzył nowy styl literacki, zwany Krytycznym Patriotyzmem. W swych wierszach starał się ujawnić społeczne problemy Węgier, starając się zainicjować niezbędne jego zdaniem przemiany na podstawie: http://www.poezje.hdwao.pl/autor 458 -endre ady. html (odczyt 04.04.2014 r.) 
cztery nazwiska i wciąż pojawiały się nowe $\mathrm{e}^{23}$. I tutaj pojawiły się problemy z paszportem. Poetka wielokrotnie pisała do konsulatu, dwa razy posyłała swój paszport do Bukaresztu przez upoważnione osoby. Upoważnionym osobom odmówiono, a na listy nie otrzymała żadnej odpowiedzi. W końcu jak wspominała sama Iłłakowiczówna, przyszedł „karteluszek” potwierdzający, że się zarejestrowała w Konsulacie w 1946 roku, to jednak nie dowodziło, że była obywatelką Polski. Zastanawiała się także jakie są powody niemożności odnowienia paszportu osobie przebywającej za granicą, której dokumenty straciły ważność w roku 1941. Wspomniana sytuacja rzutowała w znaczny sposób na dalszy pobyt kobiety z dala od domu. Wysoki koszt jazdy do Bukaresztu i pobyt na miejscu, brak moźliwości jazdy bez specjalnego zezwolenia policji, następnie niemożność zgłoszenia się do policji bez prawomocnego dokumentu i uzyskania dokumentu bez osobistego zgłoszenia się w Bukareszcie to błędne koło, które trwało od maja 1946 roku $^{24}$. Drobnym, ale podtrzymującym na duchu przełomem było przesłanie Iłlakowiczównie przez Juliana Tuwima paczki z polskimi gazetami, a wśród nich znalazły się „Głos Ludu”, „Życie Warszawy”, „Kuźnica” czy „Przekrój”. Pod koniec stycznia 1947 roku poetka potrzymała list od Tuwima, w którym napisal, że nie śmie namawiać jej do powrotu do kraju, a jedyną zachętą ku temu miało być stwierdzenie, że on sam jest bardzo szczęśliwy, że wrócił do Polski. Przekonywał ją także, że bez względu na to, czy wróci do kraju, czy też nie, zawsze jej pomo$\dot{z} \mathrm{e}^{25}$. W odpowiedzi na ów list poetka wyraziła prośbę, by wpłynąć na placówkę w Bukareszcie, aby wydała długo oczekiwane dokumenty, gdyż bez nich wyjazd z Klużu był niemożliwy. Nieoczekiwanie w wyniku starań Juliana Tuwima paszport dla Kazimiery Iłłakowiczówny dotarł wreszcie do Klużu, tym samym w pierwszych dniach listopada poetka znalazła się w Bukareszcie, gdzie oczekiwał na nią pokój w hotelu i upragniony bilet do Warszawy. W ten sposób spełniło się marzenie poetki, powróciła

23 J. Ratajczak, dz.cyt., s. 40 .

24 Tamże, s. 40-41.

2.5 Tamże, s. 41. 
do ojczyzny, a na dworcu wraz z autem oczekiwał na nią Prezes Związku Literatów Polskich Jarosław Iwaszkiewic $z^{26}$ i Juliusz Starzyński ${ }^{27}$.

Rumunię Iłłakowiczówna postrzegała jako ,miłe” miejsce, gdzie wszystko przychodzi, łatwo i lekko, podkreślała przy tym bardzo wyraźnie, że to życie codzienne w Polsce przysparza wielu zmartwien, to tam rozgrywają się dramatyczne wydarzenia. Ludność Rumunii charakteryzuje w bardzo pozytywny sposób: podkreśla ich muzykalność, zwinność ruchów, łatwość w wyczuciu nastroju i upodobań obcego człowieka, a także umiejętność doskonałego prowadzenia rozmowy, a co za tym idzie dar krasomówczy ${ }^{28}$. Podkreśla także wrażliwość na piękną formę słowa. Z podziwem wypowiadała się o urodzie rumuńskich kobiet, rozmiłowanych w różnobarwnych strojach ludowych, często haftowanych własnoręcznie. Piękno wspomnianego kraju poetka dostrzega niemal wszędzie- obserwując Rumunki wychodzące $z$ kościoła, zamyśloną kobietę handlującą serami lub owocami, dzieci spacerujące wzdłuż jarmarku. Jak przekonywała sama Iłłakowiczówna:

... wszystko to zdaje się poruszać w ramach ustalonych prawideł piękna, niechybnie dziedziczonych przez pokolenia i stosowanych w każdej chwili bez przymusu i bez samowiedzy ${ }^{29}$.

Tematem rozważań poetki jest także uroda rumuńskiej wsi, a w szczególności wiejskie zabudowania, które charakteryzują się dużą różnorodnością. W izbach mieszkalnych znajduje się mnóstwo przedmiotów, a wśród nich: barwnie wyszywane poduszki, kilimy, ręczniki, dywany, ceramika czy ręcznie malowane obrazki święte. Wszystko to tchnie pięknem, a bizantyjskie inspira-

26 Jarosław Iwaszkiewicz - poeta, prozaik, publicysta. Pseudonim: Eleuter, Kazimierz Bazar, Roman Roński. Urodzony 20 lutego 1894 roku we wsi Kalnik na Kijowszczyźnie, w rodzinie kresowej inteligencji szlacheckiej, syn Bolesława Iwaszkiewicza- powstańca z 1863 roku, urzędnika miejscowej cukrowni i nauczyciela prywatnego oraz Marii z Piątkowskich, spokrewnionej z rodziną Szymanowskich. Debiutował wierszem Lilith, ogłoszonym w jednym numerze pisma „Pióro”, wydanym w Kijowie. Związany z grupą poetów skupionych wokó1 pisma „Pro arte et studio”, wszedł w skład grupy zwanej Skamandrem. Publikował w „Kurierze Polskim”, „Kurierze Lwowskim”, „Tygodniku Ilustrowanym”. Zmarl 20 marca 1980 roku w Warszawie, na podstawie: Iwaszkiewicz Jarosław 1894-1980 [w:] Wspólcześni polscy pisarze..., dz. cyt., s.317- 319 .

27 Juliusz Starzyński ur. 28 lutego 1906 roku, zm. 11 grudnia 1974 roku, historyk sztuki, krytyk. Profesor Uniwersytetu Warszawskiego, a także członek Polskiej Akademii Nauk (PAN), na podstawie: http://www.chronologia.pl/biogram-stju1906022810.html (odczyt 04.04.2014 r.)

28 K. Ilłakowiczówna, Wspomnienia i reportaże, Warszawa 1997, s. 102-103.

29 Tamże, s. 105. 
cje widoczne w rumuńskiej ikonografii spotykają się z „latyńską wesołością"30. Iłłakowiczówna wspomina także odczyt o Marszałku Piłsudskim w Jassach, który odbył się 12 maja w drugą rocznicę jego śmierci. I tym razem podkreśla zalety rumuńskich słuchaczy, wskazując na ich skupienic, uderzającą wrażliwość, słuchających z przejęciem, ale także niezmiernie wrażliwych na piękno słowa. Samą miejscowość porównuje z Wilnem, ze względu na położenie pośród pagórków tonących w zieleni, ale także ze względu na charakterystyczne zabudowania mieszkalne przypominające „dworki” wileńskie. Ponadto dzielnica żydowska, cmentarz na wzgórzu, cytadela i kościół - usadowione na górze, jest w tym wszystkim coś wileńskiego ${ }^{31}$.

Nieodłącznym elementem wojny, która sprawiła, że poetka znalazła się w Rumunii, była rosnąca tęsknota za ojczyzną, domem. Tym, co najbardziej wyróżnia poetykę literatury emigracyjnej, a tym samym poetykę Iłłakowiczówny jest specyficznie ukształtowana przestrzeń wizji świata w jej wojennej twórczości. Świat jawi się zawsze jako podzielony. Dzieli się na Tu i Tam, między którymi przebiega wyraźna granica ${ }^{32}$. Tu-ma wartość umowną. Czaplejewicz podkreśla, że ,jest to świat trochę nieuchwytny, nieistotny, nie tylko ze względu, że jest mniej ważny, ale również z powodu, że nie posiada substancjonalnej i materialnej istoty, jakiegoś stałego punktu oparcia-jest, więc w swojej ruchliwości ulotny, stąd Iłłakowiczówna pisze w następujący sposób:

\begin{abstract}
Nim wydeptałam sobie własną ścieżkę w tym pomylonym jakimś raju ziemskim, dni upływaly mi na borykaniu się z otoczeniem - jak mniemałam- dla jego, tego otoczenia, dobra, a noce na obliczaniu możliwości, kiedy też zostanę wezwana do prawdziwej roboty. To, naokoło, i tak było tylko tymczasowe, było czymś, za co nie miało się odpowiedzialności, czymś, do czego, jak sądziłam, ani daru wyższego myślenia, ani wyższej organizacji, ani darów języków nie można było przecie zastosować, bo to leżało na takim braku poziomu, że nie widać było nawet, jak się tam schodzi. Na samą myśl o uczeniu się nowego języka groza czlowieka ogarniała ${ }^{33}$.
\end{abstract}

Przeciwieństwem Tu jest Tam, które zawsze jest stałe i nieruchome, a także ściśle określone, konkretne, niezastąpione. Staje się jedynym biegu-

30 Tamże.

31 Tamże, s. 110.

32 E. Czaplejewicz, Poetyka literatury emigracyjnej [w:] Ktokolwiek jesteś bez ojczyzny...Topika polskiej wspótczesnej poezji emigracyjnej, pod red. W. Ligęza, W. Wyskiel, Lódź 1995, s. 47.

33 K. Ithakowiczówna, Niewczesne wynurzenia, dz. cyt., s. 51-52. 
nem w całej przestrzeni literatury emigracyjnej i zarazem najbardziej trwałym, stabilnym, niezmiennym układem odniesienia. Kreowanie Tam polega na daniu pierwszeństwa emocjom i wartościowaniu przed prawdą i faktycznością. Stąd najdrobniejszy szczegół tej przestrzeni np. krajobrazowy, nie występuje w twórczości sam, lecz w specyficznej otoczce: emocjonalno-wartościującej"3.

Wszystko jest tu inne niż u nas. Wiem o tym już tylko teraz rozumowo, przyzwyczaiłam się bowiem do tej inności i stała mi się ona swojska, swojska nawet jesienią, kiedy zrazu najwięcej zawsze tęskniłam. Bo kiedy w Polsce zaczynają się słać liście i szuszczeć a szeleścić po wszystkich dróżkach parków, które tak przywykłam lubić... Ale mniejsza o to.... ${ }^{35}$.

Poza tym ukształtowanie przestrzennej wizji świata w literaturze emigracyjnej wyróżnia się pewnego rodzaju napięciem między Tu i Tam. Napięcie to kieruje się zawsze w jedną stronę: od Tu do Tam. Wyraża się szczególnym natężeniem uwagi i pamięci, woli, rozumu i uczuć; jakiś obsesyjnym zawracaniem się (,wracaniem”) do miejsc odległych ${ }^{36}$. Z przestrzenią nieodłącznie związany jest czas. Czas jest dla emigrantów źródłem udręki. Tylko izolacja od czasu bieżącego, teraźniejszego oraz ucieczka w marzenia do minionych czasów dzieciństwa dają poczucie szczęścia ${ }^{37}$ :

Czasu nie ma; został on wymyślony dla wyrażenia braku ciągłości wewnątrz nas samych, braku poczucia wieczności, którą się ciągle tylko przeczuwa, której się desperacko szuka w różnych dziedzinach - w miłości, we władzy, w sztuce i - szuka nadaremnie ${ }^{38}$.

Najważniejszą i najogólniejszą cechą egzystencji poety emigracyjnego jest bezdomność. Może ona przyjmować różne konkretyzacje: tułactwa, wygnania, pielgrzymowania. W, wojennym” okresie życia poetki dominuje poczucie osamotnienia:

Ilekroć w pierwszych miesiącach wygnania wyszłam ze swojej samotności do tego niewielkiego i ciągle zmieniającego się grona rodaków, które przesuwało się przez na-

\footnotetext{
34 Tamże, s. 48.

35 Tamże, s. 120.

36 E. Czaplejewicz, $d z . c y t$., s. 49.

37 Tamże, s. 51.

38 Tamże, s. 95.
} 
sze miasteczko, zawsze napotykałam się u nich na tę samą formę cierpienia, wyrażającą się w pretensji do tylu, tylu osobistości i osób, aż przestałam szukać kontaktu ze współwygnańcami. Stan ich był jakby zwielokrotnionym odzwierciedleniem tego, co przetrawiałam w sobie w najgorsze moje godziny ${ }^{39}$.

$\mathrm{W}$ innym miejscu pisała:

Niejeden z nas po klęsce był jak rozpędzona maszyna, doskonale narychtowana, narządzona, naoliwiona, którą nagle wstrzymano w gwałtownym ruchu ${ }^{40}$.

Rumunia zajmowała we wspomnieniach Kazimiery Iłłakowiczówny szczególne miejsce. Z jednej strony była kolejnym punktem jej „wędrówki przez życie", tułaczki, która przysparzała jej zmartwień, niepokojów i osamotnienia, $z$ drugiej natomiast strony stała się jej bardzo bliska. $Z$ wielkim zachwytem wspominała ten piękny kraj o bujnej roślinności, słynący z gościnności ludzi, gdzie mogła niedługo po śmierci Marszałka Józefa Piłsudskiego mogła wygłaszać odczyty dotyczące jego osoby i gdzie zostawiła cząstkę siebie. Była także dozgonnie wdzięczna za możliwość obcowania z rumuńską kulturą, językiem.

\section{Bibliografia}

\section{Artykuly, szkice:}

Brzozowska A., Pliszka w jaskini lwa, czyli pierwsza dama urzędów Drugiej Rzeczypospolitej, „Kobieta i życie” 1989, nr.43.

Czaplejewicz E., Poetyka literatury emigracyjnej [w:] Ktokolwiek jesteś bez ojczyzny...Topika polskiej wspólczesnej poezji emigracyjnej, pod red. W. Ligęza, W. Wyskiel, Łódź 1995

Daniclewska Ł., Kazimiery Illakowiczówny droga do Polski, „Poezja” 1978, nr 11/12.

Dybciak K., Proza o najdalszych Kresach, „Kresy” 1993, nr 15.

Fiałkowski T., Przypomnienie Illakowiczówny, "Tygodnik Powszechny" 1994, nr 28.

Korniłowiczówna M., Wnuczka Promienistego Tomasza, „Odra” 1983, nr 9.

\footnotetext{
39 K. Illakowiczówna, Niewczesne wynurzenia, dz. cyt., s. 47.

40 Tamże, s. 48.
} 
Kuncewicz P., Kazimiera Illakowiczówna, „Tygodnik kulturalny” 1963, $\operatorname{nr} 28$.

Kwiatkowski J., Lew i straszydlaki [w:] tegoż, Notatki o poezji i krytyce, Kraków 1975.

Lalak M., Arcysluch Illakowiczówny, „, Nowe Książki” 1997, nr 2.

Lichański S., Liryka Itłakowiczówny [w:] tegoż, Literatura i krytyka, Warszawa 1956.

Ławecki T., Poznańska suita Iłły [w:] Szlakami sławnych Polaków. Różnorodne oblicza wielkości, b.w., J. Łukasiewicz, Z Ilłakowiczówna po latach, „Więź” 1998, nr 9.

Maciejewska S I., Utożsamiona ze światem. Kazimiera Illakowiczówna [w:] Poeci dwudziestolecia międzywojennego, t: 1, Warszawa 1982.

Mamoń B., O wierszach Kazimiery Illakowiczówny, „Tygodnik powszechny" 1955 , nr 15.

Podhorska-Okołów S., Księga tęsknoty, „Twórczość” 1959, nr 1 [Niewczesne wynurzenia rec.].

J. Ratajczak, Itla proza, „Nowe Książki” 1997, nr 10.

J. Siedlecka, Panna Kazimiera [w:] Wypominków ciag dalszy, Warszawa 1999.

Szewc P., Trzy wybory, „Nowe Książki”1996, nr. 4.

Zan-Czerwijowska B., Kazimiera Illakowiczówna. Lata dziecinstwa i mlodości (1) „W Drodze” $1991 \mathrm{nr} 2$.

Żuliński L., Godziny z IHq, „Literatura” 1988, nr 4.

\section{Wspomnienia}

Iłłakowiczówna K., Niewczesne wynurzenia, Warszawa 1958.

Iłłakowiczówna K., Wspomnienia i reportaże, Warszawa 1997.

Ratajczak J., Lekcje u Itlakowiczówny (szkice, wspomnienia, listy i wiersze), Poznań 1986.

\section{Slowniki}

Wielka Ilustrowana Encyklopedia Powszechna, tom XIV, Kraków 1998

\section{Strony internetowe}

http://www.literatura.gildia.pl/tworcy/piotr_feliks_wilk_witoslawski

http://www.poezje.hdwao.pl/autor_458-endre_ady.html 